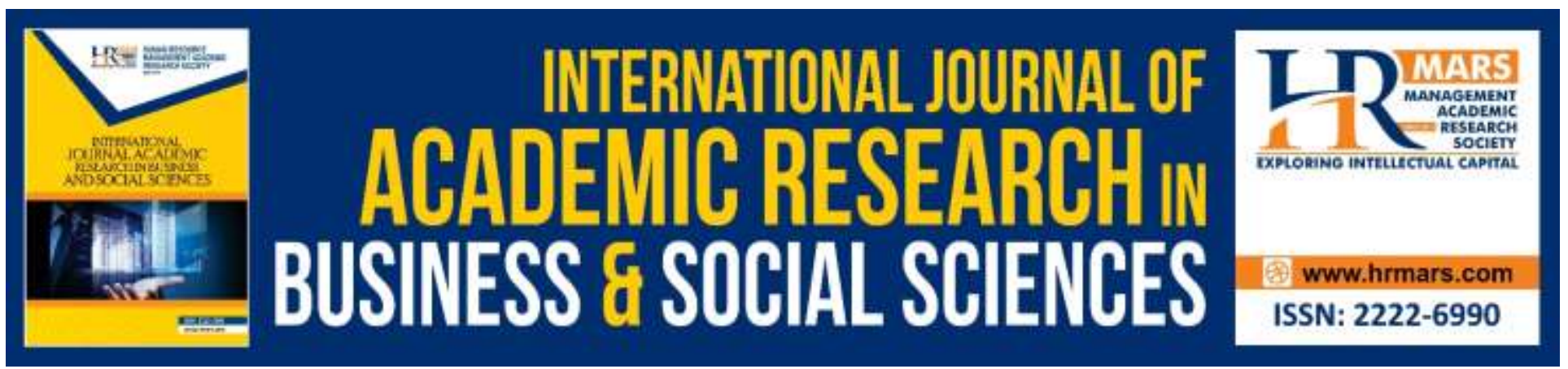

\title{
Laws of Islamic Banking in Nigeria: Critical Review and Best Practice Proposal
}

Ishaaq El-Mubarak, A. M. O, Zakariya Mustapha, Abdul Majid Tahir Bin Mohamed, Garba Ibrahim

To Link this Article: http://dx.doi.org/10.6007/IJARBSS/v10-i3/7020

DOI:10.6007/IJARBSS/v10-i3/7020

Received: 24 January 2020, Revised: 03 February 2020, Accepted: 24 February 2020

Published Online: 22 March 2020

In-Text Citation: (Ishaaq El-Mubarak et al., 2020)

To Cite this Article: Ishaaq El-Mubarak, A. M. O., Mustapha, Z., Mohamed, A. M. T. Bin, \& Ibrahim, G. (2020). Laws of Islamic Banking in Nigeria: Critical Review and Best Practice Proposal. International Journal of Academic Research in Business and Social Sciences, 10(3), 29-42.

Copyright: (C) 2020 The Author(s)

Published by Human Resource Management Academic Research Society (www.hrmars.com)

This article is published under the Creative Commons Attribution (CC BY 4.0) license. Anyone may reproduce, distribute, translate and create derivative works of this article (for both commercial and non-commercial purposes), subject to full attribution to the original publication and authors. The full terms of this license may be seen at: $\underline{\text { http://creativecommons.org/licences/by/4.0/legalcode }}$

Vol. 10, No. 3, 2020, Pg. 29 - 42

http://hrmars.com/index.php/pages/detail/IJARBSS

JOURNAL HOMEPAGE

Full Terms \& Conditions of access and use can be found at http://hrmars.com/index.php/pages/detail/publication-ethics 


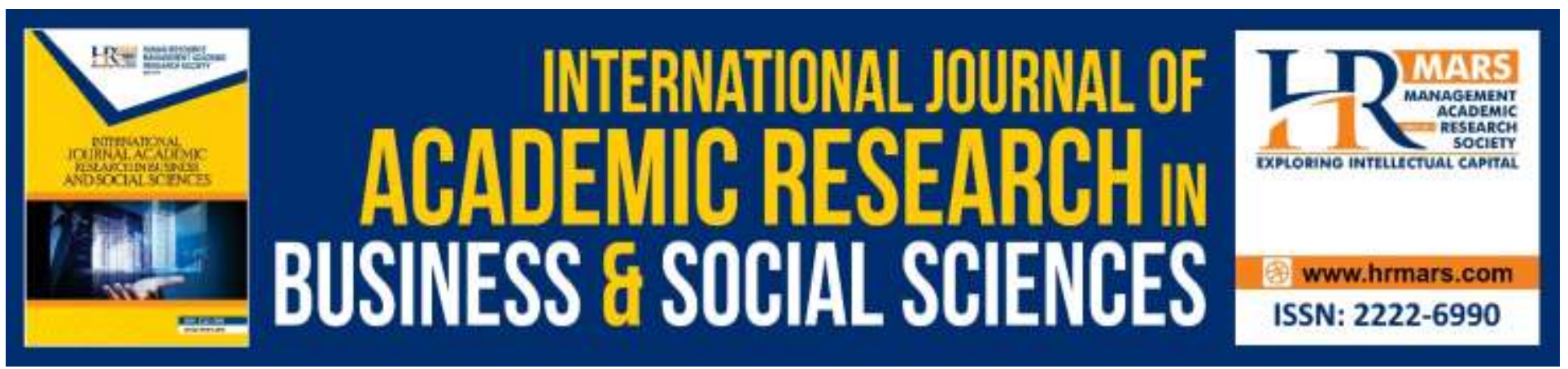

\title{
Laws of Islamic Banking in Nigeria: Critical Review and Best Practice Proposal
}

\author{
Ishaaq El-Mubarak, A. M. O. \\ LL.M Candidate, Faculty of Law and International Relations, Universiti Sultan Zainal Abidin, Malaysia
}

Email: abdulmuqadasopeyemi4sure@gmail.com

Zakariya Mustapha

Ph.D Candidate, Faculty of Law, University of Malaya, Malaysia

Email: zakariyamustapha@gmail.com

\begin{abstract}
Abdul Majid Tahir Bin Mohamed
Ph.D, Senior Lecturer, Faculty of Law and International Relations, Universiti Sultan Zainal Abidin, Malaysia

Email: amtmajid@unisza.edu.my
\end{abstract}

Garba Ibrahim

Ph.D Candidate, Faculty of Business and Management, Universiti Sultan Zainal Abidin, Malaysia Email: garbaibraheem92@gmail.com

\begin{abstract}
Strength of a regulatory regime could be discerned from progress in a concept(s) it seeks to implement and govern. Islamic banking (IB) is a concept practiced in Nigeria under conventional banking regulatory laws. The conventional laws are however not particularly meant for Islamic banking, a fact that leaves much to be desired for Islamic banking practice. A large Nigerian muslims population desirous of Islamic banking services has provided Islamic banking with supportive client base in the country. Regulatory laws have provided for Islamic banking and finance to be integrated into existing conventional system in countries with less muslims population like the UK and US. In light of this, the establishment of Islamic banking under the Nigerian conventional banking laws is critically examined in the light of Malaysian jurisdiction. Banks and other Financial Institutions Act (BOFIA) 1991, the principal Nigerian banking legislation, merely provides for non-interest banking to operate across the country which a non-interest bank known as Jaiz Bank International Plc was licensed. This study examines BOFIA and other regulations applicable to Islamic finance business and institutions in Nigeria. The study adopts a narrative review approach to deduce and examine lacunae
\end{abstract}


INTERNATIONAL JOURNAL OF ACADEMIC RESEARCH IN BUSINESS AND SOCIAL SCIENCES

Vol. 10, No. 3, March, 2020, E-ISSN: 2222-6990 @ 2020 HRMARS

in the applicable laws. Consequently, findings reveal that the applicable laws are insufficient and inefficacious to successfully drive IBF practice. Thus, suitable establishment and regulatory laws are needed to enhance IB practice, ensure its equal treatment like the conventional banking system and sustain its operations and institutions in Nigeria. Accordingly, it is recommended that extant laws and institutions be appropriately amended borrowing a leaf from Malaysian and align Nigerian legal regime on IB with global and standard best practice.

Keywords: Islamic Banking, Regulatory Laws, Lacunas, Amendment, Bofia, Nigeria.

\section{Introduction}

There is an evident difference between the emergence of Islamic banking laws and the commencement of non-interest financial services in Nigeria. Previous literature analysis revealed that no particular provision of any legislation acknowledged Islamic banking as a concept until the enactment of Banks and other Financial Institutions Act (BOFIA) in the year 1991. Sections 23 and 61 of BOFIA considerably confirmed the approval of Profit and Loss Sharing bank across the country.

In the early times, different attempts were proposed between 1961-2003 to inaugurate a financial system which offered Shariah certified products and services in Nigeria. However, these attempts were not realized due to various hurdles such as ineffective regulatory framework, legal constraints and low orientation about the banking system contents (Aburime \& Alio, 2009).

In discussing the commencement of non-interest banking operation in Nigeria, it is salient to differentiate Islamic banking window from its full-fledge at this juncture. Defunct Habib Nigeria Bank Ltd was considered as the earliest bank to offer non-interest banking windows in the history of Nigeria. The approval of the bank was delayed for several years. While Defunct Habib Nigeria Bank Ltd was later granted permission to initiate non-interest banking windows in 1996, it is unfortunate that the absence of legal support shortened its lifetime. Thereafter in 2011, Jaiz International Bank Plc was established and unanimously considered as the first full-fledged Islamic Bank in Nigeria (Abubakar, 2012).

The objective of institutionalizing Islamic banking was also supported through the establishment of Islamic Finance Working Group which was ably assisted by Enhancing Financial Innovation and Access (EFIA), Nigeria Deposit Insurance Corporation (NDIC), National Insurance Commission (NIC), Pension Commission (PC), Debt Management Office (DBO), Central Bank of Nigeria (CBN) and the likes. In fact, towards this objective, CBN in 2009 joined Islamic Financial Service Board (IFSB) as a full member of the council and simultaneously released the draft framework for the regulation and supervision of Islamic banking in Nigeria for stakeholders' remark and recommendation in that same year. Accordingly, stakeholders' view eventually triggered the issuance of non-interest banking models from the management of CBN as CBN categorized Islamic banks as part and parcel of specialized banks.

Aside from those efforts, NDIC likewise issued a draft framework for Islamic Deposit Insurance Scheme. Despite the immeasurable outcry that came with the inception of Islamic banking in Nigeria, CBN still manages to associate itself with 11 other central banks across the globe together with 2 
INTERNATIONAL JOURNAL OF ACADEMIC RESEARCH IN BUSINESS AND SOCIAL SCIENCES

Vol. 10, No. 3, March, 2020, E-ISSN: 2222-6990 C 2020 HRMARS

multilateral organizations. It is noteworthy that the logic behind these collaborations is to structure International Islamic Liquidity Management Corporation (IILM) in the country. In support of these goals, CBN in 2011 ultimately released a framework for the regulation and supervision of Islamic banking in Nigeria (Sanusi, 2011).

Remarkably, it was the legitimate permit provided for non-interest banking operation that paved a way for the existence of Jaiz Bank Plc in Nigeria. In essence, if not for the fact that some sort of legal support accompanies Islamic banking in Nigeria, the accommodation of Jaiz Bank Plc under the existing conventional model might have not been possible in the Nigerian context (Aliyu, 2014).

In this regard, this study aims to evaluate the adequacy and effectiveness of the laws applicable to Islamic banking in Nigeria. The remaining sections of this research are designed as follows: Section 2 presents the methodology of the study; Section 3 focuses on the key discussions while Section 4 represents the conclusion of the study.

\section{Objectives of the Study}

- To examine the establishment of Islamic banking under Nigerian conventional banking laws

- To evaluate BOFIA and other regulations applicable to Islamic finance business and institutions in Nigeria

- To compare major legislation of Islamic finance business in Nigeria and Malaysia respectively (BOFIA \& IFSA)

- To highlight areas that require considerations and amendments.

\section{Methodology}

One of the focuses of the research is to establish the reasons behind the existence of inadequate wordings, phrases and general provisions in the laws relevant to Islamic banking in Nigeria. Towards addressing these reasons, researchers quantify and analyse the connotations and relationships of these inadequate as well as misleading texts alongside the development of IBF services. Hence, content analysis was constructed through a comparative study between BOFIA (1991) and the Islamic Financial Services Act (2013). This methodology measures the Nigerian legal framework against one that is considered a model globally, i.e. the Malaysian. Thus, in the context of this study, the use of this methodology is justified as it suitably helps in identifying loopholes that exist in the primary legal framework of IBF in Nigeria (BOFIA).

\section{Discussion}

This sub-topic shall examine establishing laws for Islamic banking in the Federation of Nigeria. Attempts for establishing non-interest banking system wouldn't have been possible without proper back-up from several legislations. In fact, the absence of some important provisions in these legislations might have only positioned Islamic banking in a mere dream in the context of Nigeria. The reality is that section 61 of BOFIA (1991) reveals non-interest financial method as a recognized pattern under the Nigeria financial system (Olayemi, 2011). 
INTERNATIONAL JOURNAL OF ACADEMIC RESEARCH IN BUSINESS AND SOCIAL SCIENCES Vol. 10, No. 3, March, 2020, E-ISSN: 2222-6990 @ 2020 HRMARS

Legally speaking, any commercial activity without the support of any legislation providing its legality and limitations will be rendered invalid until the contrary is proven. Perhaps, these legislations still have slight, moderate or major remarks in respect of non-interest banking system in Nigeria. Basically, some laws touch the operational aspects, while others influence the structural pattern of Islamic banking. When certain legislations effect product model, others provide the validity of the product and services. In this regard, the level of support each legislation has towards the standardization of non-interest banking service in Nigeria will be analysed as follows:

\section{Constitutional Endorsement for Islamic Banking Practices}

This is the supreme and founding law for other laws across the federation (Section 1(1) Constitution of the Federal Republic of Nigeria, 1999). This law is so powerful that it prevails over other laws or statutes with maladjusted provisions in the course of contradictions.

In spite of the fact that many laws tapped their respective root and mandate in the Constitution, findings show that before the promulgation of the constitution, there is no outright declaration of Islamic banking in Nigeria. One of the main themes of the constitution is that it affirms religious liberty. The distinctness of Section 38(1) of the Constitution makes it a possible task to demand for doctrine entitlements. The affirmation of the above section unlocks the spreading of faith ideologies across the nation, of which Islamic banking is not an exclusion (Alkali \& Buang, 2017). Thence, it is quite defensible that non-interest banking service which is one of the Islamic-faith ideologies encouraged by the constitution possesses statutory support from the federal constitution. Similarly, discrimination avoidance which is among the paramount elements of Islamic banking is specially covered in the constitution. As a matter of fact, equitable and unbiased treatment will be applied to any issue sharing the features of races, religion and political affairs throughout the country (Section 42(1) CFRN, 1999). Moreover, a favourable provision in support of the formulation of the non-interest bank could also be found where the constitution proclaims for commerce association (Section 40, CFRN 1999). Therefore, it is evident from the above provisions that constitutional contribution towards the expansion of Islamic banking is indeed scanty to convince antagonists about the establishment of Islamic banking in Nigeria. Hence, it is hoped that an efficient amendment will be made to the existing provisions relating to financial institutions in the constitution.

\section{Banks and Other Financial Institutions Decree (BOFID), 1991 And the Amendments}

The study of Islamic banking laws in Nigeria is incomplete without the contributions of BOFIA. As far as non-interest banking service is concerned, the Act is one of the earliest statutes which allows its operation throughout Nigeria. Based on the Act, Islamic banking is classified under 'specialized banks' and referred to as non-interest financial institutions (Sanusi, 2011). Besides, draftsmen of BOFIA mindfully exempted non-interest financial operation from exhibiting lending and deposit interest rates (Section 23(1), BOFIA 1991).

Apart from the extraordinary treatment being presented above, the Governor of CBN is officially empowered to detach Profit and Loss Sharing Banks from being influenced by BOFIA provisions and rules (Section 52, BOFIA, 1991). This simply means that any financial crisis affecting conventional banks will not as well affect the unconventional ones, particularly those guided by Shariah principles. 
Besides it is indeed important to state that the positive impact of this Act on the development of Islamic banking in Nigeria is unforgettable. This could be acknowledged through a microscopic view of the Act itself where the Act paved a road for the establishment of non-interest financial institutions. Due to the above supports, it is understandable that removing this Act in Islamic banking exercise throughout the country is like extracting the root of its main structure (Alkali \& Buang, 2017).

\section{Central Bank of Nigeria (CBN) Act 2007}

All banks without special reference to Islamic banks are operating under the regulatory structure of this Act. CBN which coordinates each financial institution across the nation constitutes its governing body under the CBN Act 2007 (Bambale, 2007).

One of the strategies adopted by CBN was that a framework was introduced for non-interest banks to operate at the monetary market. This was achieved through the Islamic window model, wherein every conventional bank is permitted to offer Shariah certified products and services. This is because conventional banks dominate the country. Also, such bank offering those Islamic products will not concurrently promote any conventional product contrary to Islamic principles under the same platform (Section 2 (a), Central Bank Act, 2007).

Another attempt proposed by the drafters of the Act towards the expansion of Islamic banking was the formation of a Shariah Advisory Committee. The primary duty of this advisory-committee which is otherwise known as the CBN Shariah Council is to counsel the CBN regulators about Islamic law of transaction matters (Section 2 (c) Central Bank Act, 2007).

\section{Guidelines on Institutions Offering Non-Interest Financial Services in Nigeria}

To complement the goal of institutionalizing non-interest banking services across the nation, several guidelines were issued with the aim of accelerating the banking operations. Purposefully, these Guidelines were fundamentally enacted for the sake of non-interest financial institutions in Nigeria. Nonetheless, these efforts are yet to drive the system up to the progressive state.

The Guidelines clearly describe the kind of banks that will be given operational-permit in Nigeria without excluding Islamic banks (Section 4 (2), Regulation on the Scope of Banking Activities and Ancillary Matters, 2010). Stakeholders' view, opinions and suggestions are the predominant reasons behind the introduction of the new guidelines. Some important elements are inserted in the new Guideline. For instance, the definition of 'non-interest banking' now includes both forms of noninterest banking stated in BOFIA. It is important to add that discrimination is strictly forbidden among stakeholders.

During the amendment process, the identity of Islamic-law experts popularly known as Sharia Council was also changed to Advisory Council of Experts (ACE) whose primary assignment is to advise CBN on compatible and marketable financial products available at the financial market.

These Guidelines also prescribe that any contract containing the ingredients of interest, uncertainty, gambling, speculation, unjust enrichment and exploitation practices shall be rendered invalid. 
INTERNATIONAL JOURNAL OF ACADEMIC RESEARCH IN BUSINESS AND SOCIAL SCIENCES Vol. 10, No. 3, March, 2020, E-ISSN: 2222-6990 @ 2020 HRMARS

Besides, the goal of these Guidelines is to set an operational minimum standard for non-interest banking in Nigeria. Approval procedures, requirements and application fees for non-interest financial institutions are provided in these Guidelines. More so, in order to ease the banking services, templates for operating and managing the system were also outlined.

Seven Islamic financial instruments including Murabaha, Mudarabah, Musharakah, Ijarah, Salam and Parallel Salam, Istisna and Sukuk were listed accordingly in these Guidelines. However, their respective frameworks were not comprehensively detailed therein. Apart from that, an Islamic window service of conventional banks was also included in the regulations wherein cross-selling services were permitted at conventional banks. Another protective section of non-interest banking practice in the Guidelines was that Service Level Agreements (SLA) of shared services between Conventional and Islamic banks was incorporated. More so, separation of records was considered under the Islamic window agenda (Draft Framework for the Regulation and Supervision of NonInterest Banks in Nigeria, 2009). Similarly, formulation of Shariah Advisory Committee (SAC) was also allowed and commissioned with the duty of reviewing and evaluating the compliance degree of each product towards Shariah standard (Financial Policy \& Regulation Department, Central Bank of Nigeria, Abuja, 2010).

For the sake of guaranteeing adequate liquidity, non-interest banks are desired to set up wide-range policies that will be used to finance their activities. Moreover, regulators were only expected and not yet confirmed to have formulated a risk management system which entails Displaced Commercial Risk (DCR), Fiduciary Risk, Transparency Risk, Sharia Risk, Reputational Risk, Mark-up Risk etc.

Another important feature of the Guidelines is that AAOIFI standard shall often be referred to in case of lacunas (Clause 12.2, Guidelines for the Regulation and Supervision of Institutions Offering NonInterest Financial Services in Nigeria). In addition to that, special reference was also given to Islamic microfinance banks to the extent that specific Guideline was constructed to that effect. The noninterest microfinance banks whose customers are those earning low-income and people below the poverty line were strictly guided by the Advisory Committee of Experts (ACE) and CBN management. Besides, commercial transactions such as acceptance of public sector (government) deposits, foreign exchange dealings, international commercial papers, international cooperate finance, international electronic funds transfer, clearinghouse activities, leasing and renting transactions, and as well as dealings in the land were completely considered illegal under non-interest microfinance bank (NIMFB) concept (Clause 2.2, Circular on the Guidelines for the Regulation and Supervision of Noninterest (Islamic) Microfinance Banks in Nigeria, 2017). However, it is practically impossible to ban all the above elements and at the same time assume positive development in the field of Islamic banking.

Significantly, one of the Guidelines provides that sources of NIMFB fund must not exceed the likes of shareholders' fund, customer's deposit or savings, commissions, grants/donations arising from individuals, organizations or any governmental sectors. In the same way, NIMFB shall on monthly basis return documents including Mudarabah deposits, statement of profit and loss, statement of assets and liabilities, profits rate structure, non-performing financing and investment to CBN and 
NDIC in a period less than 14 days after each month ends. More so, NIMFB will be denied from funding fixed assets, equity investment and branch expansion except for the losses resulting from shareholders' fund. Hence, adopting a microscopic view into the wordings of these Guidelines, it is apparent that some Clauses were mere advice to the financial system regulators. A number of terminologies such as (Murabaha, Mudarabah, Musharakah, Ijarah, Salam and Parallel Salam, Istisna and Sukuk) were not properly and thoroughly addressed towards their operational activities in the Guideline. While those that possessed detail prescriptions are not yet effective. In fact, one of the speculative reasons behind the slow progress of non-interest banking system is that the entire members maintaining CBN department are not skilled in Islamic law, and not willing to employ IBF experts into the ministry.

Despite the fact that the above provisions are not adequate for the standard Islamic banking system as practised in Malaysia and the UK, yet, these provisions have certain contributions towards the establishment and development of Islamic banking in Nigeria.

By developing a constructive comparison between Nigeria and Malaysia, it is established that the former has no specific Act regulating Islamic banking operations, While, Malaysia has Islamic Financial Services Act (IFSA) 2013 (This Act repealed Malaysia's Islamic Banking Act 1983 and Takaful Act 1984) regulating and coordinating its Islamic banking services. Therefore, it is incompatible to compare Malaysia from Nigeria when it comes to Islamic banking operational signs of progress.

In reality, BOFIA 1991, amongst other laws, placed the IBF system into a track-line. However, apart from the fact that BOFIA was not basically designed and restricted for Islamic banking activities, its provisions are not adequate for IBF operations and services. Equally, the recent guidelines such as Guidelines for the Regulation and Supervision of Institutions Offering Non-Interest Financial Services in Nigeria (2011), Guidelines on Non-Interest Window and Branch Operations of Conventional Banks and Other Financial Institutions (2011), Guidelines for the Regulation and Supervision of Non-interest (Islamic) Microfinance Banks in Nigeria (2017), Framework for the Regulation and Supervision of Institutions Offering Non-Interest Financial Services in Nigeria (2011), Guidance Notes on Regulatory Capital for Non-Interest Financial Institutions in Nigeria (2018), Regulation on the Scope of Banking Activities and Ancillary Matters (2010) are not comprehensive enough to ensure proper expansion of Islamic banking services. Hence, substantial improvements and appropriate adjustments are highly needed to ensure standard Islamic banking practice.

\section{BOFIA and Its Amendments}

The promulgation of BOFIA has road-mapped the perversion from a single financial system in Nigeria. The financial market became more competitive since the enactment of BOFIA 1991. This is because it was during that moment that non-interest financial institutions received proper recognition and establishment under Nigeria's financial system (Idris \& Gatawa, 2018).

During the initial implementation of BOFIA, profit and loss sharing banks were exempted from some certain requirements and regulations. Regrettably, this exemption has been revoked in the recent 
INTERNATIONAL JOURNAL OF ACADEMIC RESEARCH IN BUSINESS AND SOCIAL SCIENCES

Vol. 10, No. 3, March, 2020, E-ISSN: 2222-6990 @ 2020 HRMARS

amendments by removing CBN Governor's power from such an exemption. Thus all specialised banks are subjected to general treatment beneath the Act, like its conventional counterparts.

Equally, the 1997 amendment, unfortunately, repealed section 51 and section 52 of the principal Act. Section 51 clearly excluded funds instituted under National Provident Fund Act, Nigerian Industrial Development Bank Limited, Federal Mortgage Bank, Nigerian Bank of Commerce and Industry, and the Nigerian Agricultural and Co-operative Bank Limited from the Act provisions. Whereas Section 52 , on the contrary, authorized CBN Governor to exclude PLS banks from the above order (Section 25, BOFIA, 1997 (No. 4) as amended, CAP B3, LFN, 2004). As such, the above amendment makes all the above-mentioned banks subject to the scope of the Act.

In 1998, the amendment of the Act corroded the basis and starting-point reference allocated to PLS banks amid the nation's financial laws. In this amendment, Section 9 together with its subsection (2) were changed. The removed provision was the sole provision which classified several banks minimum paid-up share capital. However, the new provision replacing the previous wordings under section 9 of the Act demands that the Bank shall from time to time designate the minimum paid-up share capital requirement of 'each category of the bank' certified and specified under the Act (Abikan, 2012).

Meanwhile, the 1998 amendment also brought positive development. Section 20(2) which had limited products of PLS banks was amended and increased to the effect that the banks may offer more Islamic banking products upon the written consent of CBN Governor (Section 11, BOFIA, 1998 as amended, CAP B3, LFN, 2004). However, the recent amendment is yet to clarify whether such consent is going to be obtained daily, sporadically, quarterly or annually. This is among the unsolved matters gaining a lot of debates amid scholars and practitioners toward the latest amendment of the Act in 2011.

A critical review of the entire amendments shows that no consideration was made towards restoring the constitution of Shariah Advisory Board (SAB). Whereas, the implication of this omission is that appropriate verification will not be conducted on each banking product, and a wrong decision will often be decided in the absence of experts' consultation (Alaro, 2009). Contrariwise, such practice does not happen in Malaysia as Islamic banking Act duly recognised the role of Shariah Advisory Board (SAB) in Islamic banking transactions (Abdulqadir, 2002). Moreover, one of the Guidelines outlining Shariah Governance for Non-Interest Financial Institutions apparently stipulates that duties, qualification and appointment procedure of Shariah board shall fall within the powers of the Governor to make regulations and decisions (CBN, 2011). Perhaps, no attempt was made with regards to the existence of SAB in the latest BOFIA in 2011 (Idris \& Gatawa, 2018). It is a fact that Shari'ah compliance system is the main trust several shareholders normally have at the back of their mind in many Islamic financial institutions (Olatoye, 2013). Thus it is pertinent for Nigerian legislators to provide provision for a governing body in the Act, as the Shariah Advisory Council of Malaysia. However, if the fixing of an Islamic name to the body also presents a major concern, then general and non-sensitive symbol other than Islamic identity should be used to describe such an advisory body. 
INTERNATIONAL JOURNAL OF ACADEMIC RESEARCH IN BUSINESS AND SOCIAL SCIENCES Vol. 10, No. 3, March, 2020, E-ISSN: 2222-6990 @ 2020 HRMARS

Therefore, it is arguable that the above amendments were not meant for remedying the applicable laws of Islamic banking in Nigeria.

\section{Loopholes in Islamic Banking Primary Legislation in Nigeria: BOFIA (1991) in Focus}

BOFIA is considered as the earliest and basic legislation which paved the way for Islamic banking in Nigeria. BOFIA Act in Nigeria financial system is in an equal position to that of IFSA in the arrangement of Malaysia banking system. The fact that the Act overlooked some salient aspects which can fasten the growth and development of Islamic banking across the federation renders it insufficient for noninterest financial institutions in Nigeria. To avoid debates, disagreements and controversies, the Act is supposed to clarify and expatiate some important areas in standard Islamic banking practice. The absence of detailed explanation about these significant areas prompted the study to identify the areas. If they are inserted in the Act, the goals of proponents of IBF system shall come to success.

The drafters of the Act posed some challenges to Islamic banking operation in Nigeria. Though BOFIA is in the major position to adequately regulate Islamic banking operation, yet, BOFIA lacks some important areas in a systemized Islamic banking system. If BOFIA is to be placed in the category of IFSA of Malaysia, it professes to entail some significant components of Islamic banking.

Every necessary ingredient included during the drafting process of Islamic Financial Services Act (IFSA, 2013) immunizes Malaysia's dynamic leadership in Islamic finance, as it developed a vigorous end-toend Shariah-compliant regulatory framework that has served as a good model for other countries. Merely looking at the provisions of IFSA, it is evident that the composition of IFSA is far comprehensive to that of BOFIA. For instance, BOFIA in every provision never jointly uses the phrase "Islamic banking". Meanwhile, section 3 of IFSA 2013 clearly makes a special provision for terms such as "Islamic banking business", "international Islamic banking business", "Islamic financial intermediation activities", "Islamic factoring business" and "Islamic leasing business" (Section 3, IFSA 2013). The possible effect of such a phrase is that readers will easily grasp the illustrated bank under the section without further clarification. One of the speculative reasons as to why Islamic banking practice still lacks behind is that BOFIA indirectly describes IBF services in Nigeria. As such, proponents and promoters of the banking system find it difficult to state it boldly that BOFIA is candidly in support of the establishment of Islamic banking in Nigeria.

Section 5 of IFSA provides the scope, types, and activities of takaful business. Whereas the fruitful result in takaful business which BOFIA does not subscribe to is that participants are joined together in cooperation and responsibilities. Charitable and benevolent acts will surely exist between the participants, and takaful plan will favour them financially and spiritually. The financial aid will ensue from the concept's plan itself, while the spiritual benefit which comes through the act of Tabarru' (donation) will descend from God's reward in this world and hereafter. Unambiguously, takaful system absolutely discourages discrimination. Besides, the fundamental function of takaful scheme is to allocate wealth among participants. Takaful practice is against creating money for money. It converts deposit and investment to genuine assets (Bhatty, 2010). Yet, upon the aforementioned benefits available in takaful plan, BOFIA overlooks the product. 
INTERNATIONAL JOURNAL OF ACADEMIC RESEARCH IN BUSINESS AND SOCIAL SCIENCES Vol. 10, No. 3, March, 2020, E-ISSN: 2222-6990 @ 2020 HRMARS

Significantly, section 6 of IFSA evidently states the regulatory objectives of the Act. Financial stability and Shariah compliance are the major goals of the entire Act. From these objectives, the extent of support the Act has for Islamic banking practice in Malaysia will undoubtedly be perceived and ascertained. However, BOFIA is silent in this aspect. This, of course, can be seen from the absence of the phrase 'Islamic banking', not to mention of Shariah compliance. Moreover, the absence of a clear goal normally delays the possible outcome of a particular plan. In light of this, it may be argued that the fundamental objectives of BOFIA are far from the minimum standard of global Islamic banking practice.

In a close relationship with that, a careful study of BOFIA shows that there is no particular headline labelled as Shariah requirements or Shariah compliance. This indicates the limited attention drafters have towards the incorporation of Islamic banking in Nigeria. Had such provision been made, the positive status of Islamic banking might have exceeded the present position. Perhaps, Part IV of IFSA (Sections 27 - 38, IFSA 2013) solely explains about the duty of institution in ensuring Shariah compliance, power of banks in collaboration with Shariah Advisory Council to identify standards on Shariah matters, the constitution of Shariah committee member and all other Shariah related matters. Besides, the importance of the above provisions in any Islamic banking regulatory laws is that the presence of similar sections will definitely strengthen the trust of consumers with IBF operational pattern.

There is no provision for designation of Islamic payment instruments in BOFIA. However, IFSA is a resourceful Act in that respect (Section 41, IFSA 2013). More so, operational arrangement will as well be designed by an operator to include: rules, procedures and requirements setting out the rights, liabilities and obligations of operator and participants; measures to ensure the safety, security and operational reliability of the designated payment system; procedures, controls and measures for the management of credit, liquidity or settlement risk, including rules determining the time when a transfer order is final in the case of payment systems; criteria for participation in the designated payment system; and measures to ensure prudent management of funds collected from the users, including measures to ensure that such funds are always available for repayment to the users (Section 45, IFSA, 2013). Unluckily, all the above-stated instruments are lacking in BOFIA.

Additionally, IFSA goes beyond the extra mile to cater for the establishment and maintenance of takaful funds in section 90 (IFSA, 2013). On the contrary, BOFIA neglects takaful plan itself, not to mention takaful funds. For instance, Section 91 of IFSA safeguards takaful funds in a way that shareholders' fund will not be mixed together with it. Apart from that, section $92 \& 93$ respectively display prerequisites pertaining to takaful funds and shareholders' fund. Conversely, the fact is that all these notable provisions are absent in BOFIA.

Similarly, business conduct standards are another unique provision under IFSA, which could not be found in BOFIA. Section 135 of IFSA declares that the Central Bank of Malaysia in its discretionary power may specify business conduct standards to any financial service provider as the case may be, for the sake of ensuring fair, transparency and professional transaction when dealing with financial consumers. Standards including transparency and disclosure requirements, the fairness of terms, 
INTERNATIONAL JOURNAL OF ACADEMIC RESEARCH IN BUSINESS AND SOCIAL SCIENCES Vol. 10, No. 3, March, 2020, E-ISSN: 2222-6990 @ 2020 HRMARS

promotion of financial services or products, provision of recommendations or advice, complaints and dispute resolution mechanisms will surely be designed by the bank. Nevertheless, despite the fact that Islamic banking gained its onset-licence from BOFIA, all the afore-listed features are not inserted.

Also, Section 141 of IFSA prescribes pre-contractual duty of disclosure, representations of takaful contracts and remedies for misrepresentations relating to takaful contracts. Equally, Section 144 restricts Minister or the bank to inquire into the affairs or account of any customer. In other words, there is a provision protecting customers' confidential information (Section 144, IFSA, 2013). Likewise, section 145 restricts Islamic financial institution, director, officer or agent of the Islamic financial institution to gain access to customer's personal account. More so, Islamic deposit service enshrined under sections 148, 149 and 150 is another unique feature which makes IFSA more comprehensive than BOFIA. Islamic money market and Islamic foreign exchange market available in section 152-154 of IFSA are among the distinct features of the Act from BOFIA. Apart from that, categories of Islamic financial intermediation activities which include the accepting of Islamic deposits, giving of any advance, financing or other facility, Islamic leasing business, Islamic factoring business, purchase of bills of exchange or other negotiable instruments and Islamic hire-purchase contained in IFSA (Section 222, IFSA, 2013) are as well significant ingredients for Islamic banking operations which could not be detected in BOFIA.

Furthermore, there is no provision relating to Shariah compliance mechanism in BOFIA. But IFSA considerately contains provisions regulating market conducts together with consumer protection (Part IX, Division 2, IFSA 2013). On the other hand, Islamic banking consumers are entirely ignored inside the BOFIA Act. Besides, the Act is equally silent on the establishment of a Shariah Advisory Board ( $S A B)$. The primary role of $(S A B)$ is to ascertain the degree of Shariah compliances in any specified product. The likely effect from not having a proper SAB is that Islamic banking operations will not run smoothly as every product will miss the chance to be subjected to thorough consultation and examination of SAB before it can be offered to the market. Also, the aspect of Islamic banking litigations is yet to be covered by BOFIA. In Malaysia, when the courts are to decide Shariah issues on Islamic banking, they are required to refer to the SAC rulings or resolutions to avoid counter-Shariah judgements (Mohamed et al., 2015; Khalid, Islam \& Ahmed, 2019; Alzgool, 2019)

Hence, to complement the above discussion, it can be argued that some BOFIA provisions are directly or indirectly contradicting Shariah standard, or may pose challenges for Islamic banking smooth operations. This simply means that the majority of the provisions are not in support of the establishment and expansion of Islamic banking in Nigeria. Therefore, it is significant to conclude that BOFIA is not adequate enough to successfully stir Islamic banking service in the Nigerian context.

\section{Conclusion}

Broad areas of influence that can be considered to represent quality Islamic banking system were absent in the applicable laws of Islamic banking in Nigeria. These laws ignored crucial-detailed explanation in certain provisions, and overlooked some salient aspects that can fasten the expansion of Islamic banking. Findings indicate that the absence of a specific Act for Islamic banking services is 
INTERNATIONAL JOURNAL OF ACADEMIC RESEARCH IN BUSINESS AND SOCIAL SCIENCES Vol. 10, No. 3, March, 2020, E-ISSN: 2222-6990 @ 2020 HRMARS

also another weaken part pulling-back IBF service across the nation. Discovery shows that BOFIA was not basically enacted for the operation of non-interest financial institutions.

Although it is a national reality that BOFIA 1991, amongst other laws, positioned non-interest system into a track-line in Nigeria, regrettably, its provisions are not adequate enough to successfully stir IBF operations. Similarly, the Guidelines provided for non-interest financial institutions are not inclusive to design the extension of the banking service. Research likewise indicates that Islamic banking system may not be accommodated with the subsisting laws, frameworks and procedures in Nigeria.

It has been observed that BOFIA is incompetent to speed-up Islamic banking progress in the country. Whereas, the subsequent amendments of the Act, instead of strengthening the available provisions in the principal Act, they rather add more ambiguities to the reliable sections of non-interest financial services. Besides, lack of pertinent adjustments, necessary improvements and significant insertions upon its 1991 initial enactment undoubtedly hinder the overall development of Islamic banking in Nigeria. Hence, serious amendments are highly needed for the entire legal framework, to enable massive encouraging performances of Islamic banking in Nigeria.

One of the significant contributions of this research is to showcase the potentials of Islamic banking towards overcoming the economic crisis. The current study critically examines the existing provisions provided for IBF in Nigeria by proposing ways of improvements and highlighting aspects that needs considerable attention. The research has important implications for legislatures and Advisory Council of Experts (ACE) who are responsible for creating laws, convincing masses and government about the productive expectations of supporting the expansion of Islamic banking across the country. The highlighted lacunas may be considered as influencing factors for hastening economic recovery. Hence, the study contributes to the field by pinpointing the missing areas that likewise complement and represent a standard Islamic banking practice.

\section{References}

Abdulqadir, I. A. (2002). Interest-free window of the Defunct Habib Nigeria Bank: A Test-Run for Islamic Banking in Nigeria. Available at www.law.unilorin.edu.ng/index.php/2013. Accessed 20 January 2020.

Abikan, A. I. (2012). The Legal Framework for Islamic Banking in Nigeria. Journal of Islamic Banking and Finance. Oct-Dec. 2012.

Abubakar, S. O. (2012). Socio-Economic and Legal Challenges of Sharia Compliant Banking Operation, its Developmental Impacts and the Struggles of the Believers: Epistemological Lessons from Nigeria. Journal of Islamic Economics, Banking and Finance. Vol. 8. Pg. 5.

Aburime, U. T. \& Alio, F. (2009). Islamic banking: theories, practices and insights for Nigeria. International Review of Business Research. Vol. 5. No. (1). Pp. 321-339.

Alaro, A. A. (2009). "Shariah Supervision as a Challenge for Islamic Banking in Nigeria". Oloyede I. O. (ed) Al-Adl (The Just): Essays on Islam, Islamic Law and Jurisprudence. Ibadan. Nigeria.

Aliyu, S. (2014). Sustainable Islamic Banking: A Conceptual Framework for Non-Interest Banks in Nigeria. International Journal of Economics, Management and Accounting. Vol. 22. No. 1. g. 18. 
INTERNATIONAL JOURNAL OF ACADEMIC RESEARCH IN BUSINESS AND SOCIAL SCIENCES

Vol. 10, No. 3, March, 2020, E-ISSN: 2222-6990 C 2020 HRMARS

Alkali, M. B. \& Buang, A. H. (2017). Legal Aspects of Islamic Banking and Finance in Nigeria. Shariah Journal, Vol. 25, No. 2 (2017). Pg. 326.

Alzgool, M. (2019). Nexus between Green HRM and Green Management towards Fostering Green Values. Management Science Letters, 9(12), 2073-2082.

Bambale, Y. Y. (2007). Islamic Law of Commercial and Industrial Transactions. Lagos: Malthouse Law Books.

Banking and Financial Institution Act (BOFIA), 1991.

Bhatty, A. (2010). The Growing Importance of Takaful Insurance. Asia Regional Seminar organised by OECD and Bank Negara Malaysia under the sponsorship of the Government of Japan. Kuala Lumpur, Malaysia. 23-24, sept, 2010.

Khalid, N., Islam, D. M. Z., \& Ahmed, M. R. M. (2019). Sentrepreneurial Training and Organizational Performance: Implications for Future. Humanities \& Social Sciences Reviews, 7(2), 590-593.

Ibrahim, B. Y. (2010). An Appraisal of the Oversight Function of the Judiciary over the Legislative and the Executive under the American and Nigerian Constitutions. Usman Danfodio University Sokoto Journal of Islamic Comparative Law (UDUSJICL). Vol. 2. Pg. 52.

Idris, I. M., \& Gatawa, N. M. (2018). Challenges of Islamic Banking in Nigeria; Legal and Regulatory Perspectives. Journal of Islamic Banking and Finance. April - June 2018. Pg. 60.

Olatoye, K. A. (2013). Legal Issues and Challenges in the Regulation of Islamic Finance in Nigeria. Ph. D Thesis (Unpublished). Faculty of Law. Lagos State University, Ojo. Pg. 229.

Olayemi, A. M. (2011). The Legality of Islamic Banking in Nigeria: A Critical Approach. Prime Journal of Business Administration and Management (BAM). Vol. 2 (2). Pg. 3.

Sanusi, L. S. (2011). "Islamic Finance in Nigeria: Issues and Challenges". Lecture Delivered at Markfield Institute of Higher Education (MIHE). Leicester: UK. 17 June 2011. 